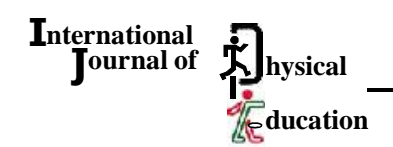

DOI : $10.15740 / \mathrm{HAS} / \mathrm{IJPE} / 7.2 / 75-77$

e ISSN-0976-7924 | Visit us - www.researchjournal.co.in

Research Paper

Volume 7 | Issue 2 | October, 2014 | 75-77

\title{
The effect of yoga practice on heart circulatory system
}

\section{ARJUN SINGH}

Author for Correspondence : ARJUN SINGH

Department of Physical Education, Dr. R.M.L. Avadh University,

FAIZABAD (U.P.) INDIA

Email: arjunsinghau@gmail.com

Received : 18.03.2014; Revised : 11.09.2014; Accepted : 24.09.2014

\section{-ABSTRACT}

The cardiovascular diseases are much on a rise ever since the past few decades in developing countries. This study was done to analyze the effect of yoga on cardiovascular and mental status in normal adult person above the age of 40 years. 50 healthy men above the age of 40 years performing yoga regularly were included in the study. The heart circulatory status was assessed by recording the blood pressure and pulse rate, before and after 6 months of regular yogic practice. On analyzing the effects of yoga in normal subjects above the age of 40 years, in the present study, it is found that there is a highly 6 months of yogic practice. The mean pulse rate (beats/min) before yoga was $89.5 \pm 4.72$, which reduced significantly to $76.78 \pm 4.26$ after 6 months of yogic practice $(\mathrm{p}<0.001)$. The mean resting systolic blood pressure $(\mathrm{mm}$ $\mathrm{Hg}$ ) before yogic practice was $138.25 \pm 4.71$ and after 6 months, it was lowered to a highly significant $(\mathrm{p}<0.001)$ level of $120.05 \pm 3.40$. The mean resting diastolic blood pressure $(\mathrm{mm} \mathrm{Hg})$ before yoga was $83.6 \pm 6.10$ and reduced significantly $(\mathrm{p}<0.001)$ to $76.4 \pm 6.35$. On the basis of results, yogic practice can be used as an intervention in ageing persons to reduce the morbidity and mortality from heart circulatory diseases.

- Key Words : Heart circulatory diseases, Normal adult person, Yoga practice

- How to cite this paper : Singh, Arjun (2014). The effect of yoga practice on heart circulatory system. Internat. J. Phy. Edu., 7 (2) : 75-77. 